\title{
Epilepsy and alcohol : the influence of social alcohol intake on seizures and treatment in epilepsy
}

Citation for published version (APA):

Höppener, R. (1981). Epilepsy and alcohol : the influence of social alcohol intake on seizures and treatment in epilepsy. [Doctoral Thesis, Maastricht University]. Rijksuniversiteit Limburg. https://doi.org/10.26481/dis.19811016rh

Document status and date:

Published: 01/01/1981

DOI:

10.26481/dis.19811016rh

Document Version:

Publisher's PDF, also known as Version of record

\section{Please check the document version of this publication:}

- A submitted manuscript is the version of the article upon submission and before peer-review. There can be important differences between the submitted version and the official published version of record.

People interested in the research are advised to contact the author for the final version of the publication, or visit the DOI to the publisher's website.

- The final author version and the galley proof are versions of the publication after peer review.

- The final published version features the final layout of the paper including the volume, issue and page numbers.

Link to publication

\footnotetext{
General rights rights.

- You may freely distribute the URL identifying the publication in the public portal. please follow below link for the End User Agreement:

www.umlib.nl/taverne-license

Take down policy

If you believe that this document breaches copyright please contact us at:

repository@maastrichtuniversity.nl

providing details and we will investigate your claim.
}

Copyright and moral rights for the publications made accessible in the public portal are retained by the authors and/or other copyright owners and it is a condition of accessing publications that users recognise and abide by the legal requirements associated with these

- Users may download and print one copy of any publication from the public portal for the purpose of private study or research.

- You may not further distribute the material or use it for any profit-making activity or commercial gain

If the publication is distributed under the terms of Article $25 \mathrm{fa}$ of the Dutch Copyright Act, indicated by the "Taverne" license above, 
People suffering from epileptic seizures are often confronted with restrictions resulting from their attacks, as exclusion from several professions, not being allowed to drive a car, being excluded from some sports and prohibition of alcohol.

This absolute alcohol prohibition could not always be realized. However, after relaxation of this prohibition no influence of alcohol on the seizure frequency could be perceived.

Consultation of manuals in order to trace the literature studies on which this prohibition was based, was unsuccessful since there was no mention of the original research from which it appeared that alcohol was provocative of seizures.

To be able to give a well-founded pronouncement on the influence of social alcohol intake on epilepsy research was undertaken with epileptic patients who had never before or very sporadically used alicohol.

During 16 weeks - twice a week - in a clinical setting 1 to 3 glasses of alcoholic beverage were used within a period of 2 hours. The examination could be carried out double blind since the drink that was chosen - vodka is adourless and can not be tasted when mixed with oranoeade.

\section{The following items were examined}

1 Does the seizure frequency change in case of social use of alcohol?

2 what is the effect of alcohal intake on the blood levels of anticonvulsants?

3 Are there any changes in the epileptic EEG actiwity induced by alcohol intake?

4 What are the attitudes of the Dutch neurologist and his foreign colleagues with regard to alcohol intake by epileptic patients?

Since the use of alcohol belongs to one of the social aspects of epilepsy. in this thesis full attention is also paid to several other social aspects of epllepsy, for instance the influence of the onset of epilepsy on the education of the child, outlook on the future, school attaimment and what factors can influence employment. Consideration is also given to the relation epilepsy-exercise as well as the conditions on which various 
countries allow driving licences to epileptics and the accident frequency of epileptic patients in comparison with a control group.

It goes without saying that special attention is paid to alcohol metabolism and the influence of alcohol intake on drugs and the electric activity of the brain cells.

There is also a review of literature on the relation alcohol use and seizures in which case it is conspicuous that this is vintually confined to the relation of alcohol abuse with the occurrence of attacks. The cooperation in the inquiry into the attitude of the attendant specialist with regard to alcohol intake with epileptic patients was very large. The response of the Dutch neurologists was very high and came to $63 \%$. From the other 24 countries in total 478 forms have been completed and returned, giving a response rate of $42,7 \%$.

The differences in attitude between the various countries were very large and so it could happen that in one country $90 \%$ of the respondents believed in an absolute alcohol prohibition, while in another country $80 \%$ of the respondents believed in social alcohol use.

\section{Conclusions}

1 No influence of social alcohoi use on epileptic seizures is demonstrable.

2 The blood levells of carbamazepine, pherabarbital and phenytoin are not influenced by alcohol intake. The valproic acid concentration is possibly slightily increased. However, this needs further examination before pronouncements can be made.

3 Both in frequency bands and in the amount of epileptic activity no change is produced by alcohol use.

4 The attitude of specialists with regard to alcohol intake by epileptic patients is very contradictory and differs very strongly between countries. 
De mensen die last hebben van epileptische aanvallen worden hierdoor nogal eens geconfronteerd met diverse beperkingen, woortvloeiende uit hun aanvallen, zoals onder andere het onbereikbaar zijn van diverse functies, het niet mogen autorijden, het uitgesloten zijn wan somige sporten en het verbieden van a icohol.

Dit absolute alcoholverbod was in de praktjjk niet altijd realiseerbaar. Na ontheffing van dit verbod kon echter geen inwloed van alcohol op de aanvals frequentie worden wargenomen.

De raadpleging van handboeken om na te gaan op welke literatuurstudies dit verbod gebaseerd was, leverde een teleurstellend resultaat op daar er geer bronvermelding was waaruit bleek dat alcohol aanvalsprovocerend was.

Ten einde een goed gefundeerde uitspraak te kunnen doen over de invloed van sociaal alcoholgebruik op epilepsie werd een onderzoek gestart bij epilepsiepatiënten, die voordien nooit of zeer sporadisch alcohol gebruikt hadden.

Gedurende 16 weken werd in een klinische setting 2 mal per week 1 tot 3 glazen alcoholhoudende drank geconsumeerd in een periode van 2 uur. Door de keus van de drank - wodka, reukloos en in sinas niet te proeven - kon het onderzoek dubbelblind worden uitgevoerd.

\section{Onderzocht werden}

1 Verandert door sociaal alcoholgebruik de aanvalsfrequentile?

2 Wat is het effect van alcoholgebruik op de bloedspiegels van de antiepileptica?

3 Treden door alcoholgebruik veranderingen op in de epileptische activiteit geregistreerd met behulp van het $E E G$ ?

4 Hoe is de houding van de Nederlandse neuroloog en die van zijn buitenlandse collega's ten opzichte van het alcoholgebruik bij epileptische patiënten?

Daar alcoholgebruik tot éên van de sociale aspecten van epilepsie behoort, is in deze thesis ook uitvoerig aandacht besteed aan diverse andere sociale aspecten van epilepsie, zoals aan: wat is de invloed van het ontstaan van epilepsie op de opvoeding van het kind, toekomstoriëntatie, 
schoolniveau en welke factoren kunnen de arbeidsrelatie beinvioeden. Daarnaast wordt ingegaan op de relatie epilepsie en inspanning, al smede welke voorwaarden zijn er in de diverse landen voor het werlemen van rijbewijzen aan epileptici en hoe is de ongevalsfrequentie van epilepsiepatiênten in wergelijking met een controlegroep?

Wanzelfsprekend is er uitvoerig stilgestaan bij het alcoholmetabolisme en wat de invloed van alcoholgebruik is op geneesmiddelen en de elektrische activiteit van de hersencellen.

ook is er een overzicht van de literatuur over de relatie alcoholgebruik en aanvalien, warbij opvalt dat er bijna uitsluitend literatuur is over de relatie alcoholmisbruik en het optreden van aanvallen.

De medewerking aan de enquête om een inzicht te krijgen in de houding van de behandelend specialist ten opzichte van het alcoholgebruik bij epilepsiepatiënten was groot. Het responspercentage van de Nederlandse neurologen was hoog en bedroeg 63 . Vanuit de overige 241 anden die deelnamen aan de enquête werden 478 formulieren ingevuld en geretourmeerd, hetgeen een responspercentage gaf wan 42,7 .

De verschillen in attitude tussen de Janden onderling waren zeer groat en 20 kon het voorkomen dat in het ene land 90\% van de respondenten voorstander was van een absoluut alcoholverbod, terwijl in een ander land $80 \%$ van de respondenten voorstander was van sociaal alcoholgebruik.

\section{Conclusies}

$1 \mathrm{Er}$ is geen invloed aantoonbaar van sociaal alcoholgebruik op epileptische aranvallen.

2 De bloedspiegels van carbamazepine, phenobarbital en phenytoine worden niet door het alcoholgebruik beinvloed. De valproinezulurcancentratie wordt mogelijk, licht verhoogd. Hiervoor is echter verder onderzoek nodig alvorens tot een zekere witspraak te komen.

3 In zowel de frequentiebanden als in de hoeveelheid epileptische activiteit treedt door alcoholgebruik geen verandering op.

4 De houding van de specialisten ten aanzien van het alcoholgebruik bij epilepsiepatiënten is zeer tegenstrijdig en kon tussen de landen onderling sterk verschillen. 